\title{
BrO, blizzards, and drivers of polar tropospheric ozone depletion events
}

\author{
A. E. Jones ${ }^{1}$, P. S. Anderson ${ }^{1}$, M. Begoin ${ }^{2}$, N. Brough ${ }^{1}$, M. A. Hutterli ${ }^{1}$, G. J. Marshall ${ }^{1}$, A. Richter ${ }^{2}$, H. K. Roscoe ${ }^{1}$, \\ and E. W. Wolff ${ }^{1}$ \\ ${ }^{1}$ British Antarctic Survey, Natural Environment Research Council, High Cross, Madingley Road, Cambridge, CB3 0ET, UK \\ ${ }^{2}$ Institute of Environmental Physics, University of Bremen, Otto-Hahn-Allee 1, 28359 Bremen, Germany
}

Received: 9 March 2009 - Published in Atmos. Chem. Phys. Discuss.: 3 April 2009

Revised: 24 June 2009 - Accepted: 29 June 2009 - Published: 17 July 2009

\begin{abstract}
The source of bromine that drives polar boundary layer ozone depletion events (ODEs) is still open to some debate. While ODEs are generally noted to form under conditions of a shallow stable boundary layer, observations of depleted air under high wind conditions are taken as being transport-related. Here we report observations from Antarctica in which an unusually large cloud of $\mathrm{BrO}$ formed over the Weddell Sea. The enhanced $\mathrm{BrO}$ was observed over Halley station in coastal Antarctica, providing an opportunity to probe the conditions within an active "bromine explosion" event. On this occasion, enhanced $\mathrm{BrO}$ and depleted boundary layer ozone coincided with high wind speeds and saline blowing snow. We derive a simple model to consider the environmental conditions that favour ODEs and find two maxima, one at low wind/stable boundary layer and one at high wind speeds with blowing snow. Modelling calculations aiming to reproduce the wider regional or global impacts of ODEs, either via radiative effects or as a halogen source, will also need to account for high wind speed mechanisms.
\end{abstract}

\section{Introduction}

Ozone depletion events (ODEs) are well-documented phenomena that are observed in coastal areas of both the northern and southern polar regions during spring (e.g. Simpson et al., 2007 and refs therein). Boundary layer ozone values can drop rapidly from background levels to instrumental detection limits and remain suppressed for several days before

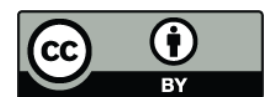

Correspondence to: A. E. Jones (aejo@bas.ac.uk) recovering. In terms of environmental conditions, it is generally observed that ODEs occur during low wind speeds (e.g. Jones et al., 2006; Jacobi et al., 2007) when the boundary layer is shallow and stratified (Anderson and Neff, 2007). Such a pseudo "reaction chamber" would enclose and therefore favour the chemical processes at play (Simpson et al., 2007). Any ODEs measured during high wind speeds have been assumed to arise from transport of air masses where the ozone has previously been depleted (Simpson et al., 2007). In some instances this is certainly the case, but we present results here that demonstrate that there are exceptions to this rule.

ODEs are a phenomenon associated with the sea ice zone. They are routinely observed at coastal locations when incoming winds have traversed sea ice covered areas. A limited number of studies have been carried out within the sea ice zone itself (Hopper et al., 1994, 1998; Ridley et al., 2003; Jacobi et al., 2007) with all reporting significant and sustained depletion of boundary layer ozone. The ozone destruction appears to be driven by halogen chemistry, predominantly involving bromine, and the now well-known reaction cycle referred to as the "Bromine Explosion" (Fan and Jacob, 1992; Tang and McConnell, 1996; Vogt et al., 1996; Lehrer et al., 2004) has been proposed to explain the observations. This cycle can be represented schematically as shown in Fig. 1, and there are two key features to note. Firstly, it is autocatalytic, with one atom of gaseous $\mathrm{Br}$ as reactant generating two $\mathrm{Br}$ atoms as product. Secondly, it is a multi-phase process, the second $\mathrm{Br}$ atom originating from the condensed phase. Images from the satellite-borne GOME (Global Ozone Monitoring Experiment) (Richter et al., 1998; Burrows et al., 1999) and SCIAMACHY (Scanning Imaging Absorption SpectroMeter for Atmospheric CHartographY)

Published by Copernicus Publications on behalf of the European Geosciences Union. 


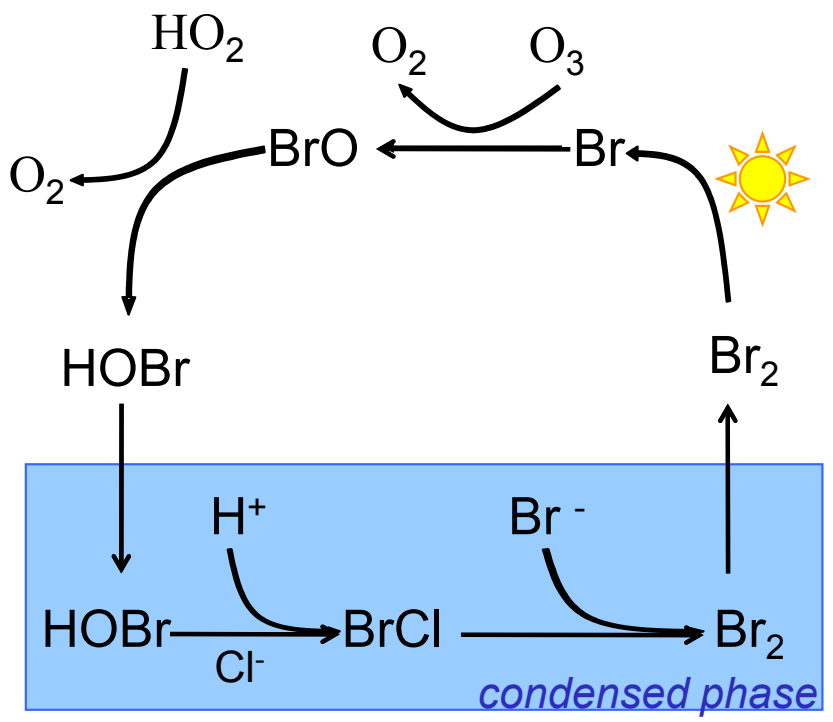

Fig. 1. Simplified schematic of the bromine explosion reactions (adapted from Simpson et al., 2007).

(Bovensmann et al., 1999) instruments have revealed enormous heterogeneity in $\mathrm{BrO}$ vertical column density over polar regions in spring, with tremendous enhancements occurring sporadically (in both time and location) across the sea ice zone (Wagner and Platt, 1998; Wagner et al., 2001; Richter et al., 2002).

Considerable debate continues regarding exactly what substrate constitutes the condensed phase that acts as a bromine atom source via the bromine explosion. However, certain facts are clear. The source is associated with the sea ice zone and its surface is saline. Suggestions for this substrate have included sea salt deposited to the snowpack (McConnell et al., 1992), acidified sea salt aerosol (Vogt et al., 1996), sea ice surfaces and/or sea salt aerosol (Frieß et al., 2004), concentrated brines on new sea ice and in frost flowers (Rankin et al., 2002; Kaleschke et al., 2004), snow and ice on first year sea ice contaminated with sea salts (Simpson et al., 2007). A recent study has considered sublimation of salty blowing snow as a source of sea salt aerosol which then acts as the bromine source (Yang et al., 2008). Certainly it is known that $\mathrm{Br}_{2}$ and $\mathrm{BrCl}$ can be produced within the snowpack, as demonstrated by field observations in the Arctic (Foster et al., 2001).

Heterogenous reactions, as required for the bromine explosion, are well known to atmospheric chemistry. In order to proceed, contact must be facilitated between the gaseous and the condensed phases. In the atmosphere there are two likely ways in which this can be achieved. For a condensed phase that is restricted to the surface of the Earth, such as the majority of those proposed for the bromine explosion, the likelihood of reaction can be enhanced by increasing the concentration of reactants in air just above the Earth's surface. Such a condition can be achieved under low wind speeds when the boundary layer is shallow and stratified, and as referred to above, this matches the conditions under which many ODEs are observed. The second option involves an air-borne substrate hosting the condensed phase, in line with the suggestion by Yang et al. (2008). In this case, any multi-phase reaction would be favoured by a high and well-dispersed surface area, and any turbulent mixing that increased air-flow around the surface.

Radiation is also required for sustaining the chain reaction, and actinic flux is likely to be modified under conditions of blowing snow. Whether enhanced or attenuated will depend upon a number of factors including the depth within the blowing snow layer, the solar zenith angle, the snow density and the wavelength. An analogy is provided by a modelling study (Lee-Taylor and Madronich, 2002) that considered light propagation through snowpack. They calculated that for SZA less than $\sim 50^{\circ}$, some actinic flux enhancement would occur in the top $10 \mathrm{cms}$ of the snowpack. This occurred as a result of enhancements to diffuse light from forward scattering that outweighed attenuation of direct radiation, such that actinic flux is enhanced. Deeper within the snowpack, actinic flux was attenuated.

A considerable challenge for understanding ODEs and the associated enhanced $\mathrm{BrO}$, is the difficulty of making observations within the sea ice zone where initiation reactions and the majority of propagation reactions occur. Thus far, a detailed study of processes occurring within a cloud of enhanced $\mathrm{BrO}$ has not been reported. However, on 9 October 2007, satellite images show a huge pool of air with enhanced $\mathrm{BrO}$ over the sea-ice covered Weddell Sea. This $\mathrm{BrO}$ cloud also lapped the shore of the Antarctic continent and encompassed the British Antarctic Survey station, Halley (see Fig. 2a). This event provides a rare opportunity to probe the environmental conditions at play during propagation of bromine enhancement. In this paper we investigate the formation of this $\mathrm{BrO}$ cloud using satellite measurements and mesoscale meteorological charts, and gain ground-truth from measurements made at Halley station. The results challenge the conventional view that a stable shallow boundary layer is an essential pre-requisite for severe tropospheric ozone depletion and show that ODEs can propagate during extreme wind events.

\section{BrO over the Weddell Sea on 9 October 2007}

The Weddell Sea is the name given to the large "bay" that lies to the east of the Antarctic Peninsula (see Fig. 2a). At its widest, it is about $2000 \mathrm{~km}$ across, and it has an area of around 2.8 million $\mathrm{km}^{2}$. During winter, the Weddell Sea is heavily iced, and considerable ice coverage is retained into the spring and early summer months. Figure 2 a shows an AMSR-E remotely sensed sea ice concentration map (Spreen et al., 2008) for Antarctica on 9 October 2007. The extensive 

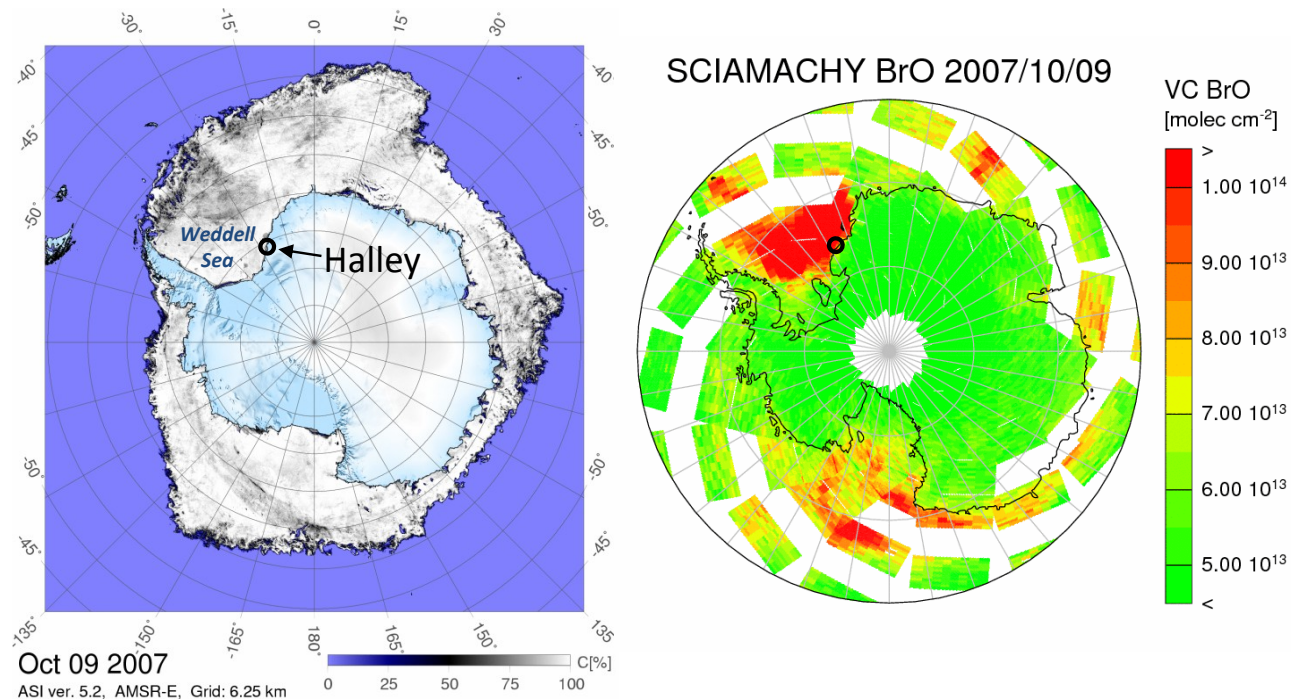

Fig. 2. (a) Map showing position of Halley, the Weddell Sea, and sea ice concentration around Antarctica on 9 October 2007. Note the extensive sea ice coverage within the Weddell Sea at this time of the year. (b) Daily-averaged BrO column density on 9 October 2007. The position of Halley is shown by the open circle.

coverage within the Weddell Sea is clear. The Southern Weddell Sea is bounded by the Filchner and Ronne Ice Shelves. Katabatic winds flowing off the continent maintain large coastal leads in this area so that the region is known to be one of new sea ice formation (Renfrew et al., 2002). Within the pack ice, leads of open water occur when wind divergence acts to stretch the ice field over large areas, balanced by compression of the pack where wind convergence occurs. Such conditions occur during synoptic storm events where winds are sufficiently strong to maintain partial open water within the pack (Wadhams, 2002).

The spatial extent of the enhanced $\mathrm{BrO}$ episode of 9 October 2007 is shown in Fig. 2b. Vertical column densities of BrO of over $1 \times 10^{14}$ molec $\mathrm{cm}^{-2}$ cover the majority of the Weddell Sea. Although enhanced $\mathrm{BrO}$ is common within the Weddell Sea region, it is unusual to find an event with such extensive coverage. Furthermore, this is the first occasion during the modern period of Halley surface ozone records (re-started in 2003) that satellite data have indicated the presence of enhanced $\mathrm{BrO}$ column densities over Halley station itself, rather than offshore.

\section{Halley ground-based observations of surface $\mathrm{O}_{3}$, me- teorology and snow salinity}

\subsection{Surface $\mathrm{O}_{3}$}

Surface ozone has been measured continuously at Halley since 2003 with a break in the record during 2005. During 2007, surface ozone was measured using a Thermo Electron model 49C, which has a detection limit of $1 \mathrm{ppbv}$, and a precision of 1 ppbv. Data are recorded every $1 \mathrm{~min}$ so the in- strument is able to capture rapid changes in surface ozone. Measurements were made at the Clean Air Sector Laboratory (CASLab) which is located $1 \mathrm{~km}$ away from the nearest station generator and in a sector that only rarely receives air from the base (Jones et al., 2008). Measurements of wind speed and wind direction are carried out at the main station, some $1 \mathrm{~km}$ from the CASLab. The anemometers and vanes are located at a height roughly $10 \mathrm{~m}$ above the snow surface, and have an accuracy of about $0.5 \mathrm{~ms}^{-1}$ for wind speed and $5^{\circ}$ for wind direction (König-Langlo et al., 1998). Data are also output every $1 \mathrm{~min}$.

Springtime ODEs are a regular feature in coastal Antarctica (e.g. Wessel et al., 1998; Jones et al., 2006; Helmig et al., 2007). Their appearance at Halley almost exclusively coincides with a change in wind direction from the prevailing easterlies to winds arriving from over the sea ice to the west. On these occasions, the change in wind direction is accompanied by a reduction in wind speed. On 7 October, such a typical ODE was measured at Halley (see Fig. 3a). The depletion event terminated on the morning of 8 October (Fig. 3a) with the arrival of an intense springtime storm. Winds of $25 \mathrm{~ms}^{-1}$ arrived at the base from the east (Fig. 3b and c) and surface ozone concentrations returned to their normal background level of roughly $30 \mathrm{ppbv}$. On the morning of 9 October wind speeds reduced slightly to $\sim 16 \mathrm{~ms}^{-1}$ but still arrived at Halley from the east (Fig. $3 b$ and c). Even under these conditions, just after 06:00 surface ozone values plummeted from background values to $\sim 5 \mathrm{ppbv}$, and continued to fall to instrumental detection limits around 09:00 (Fig. 3a). The depletion event terminated rapidly in the early morning of 10 October accompanied by an increase in wind speed. 


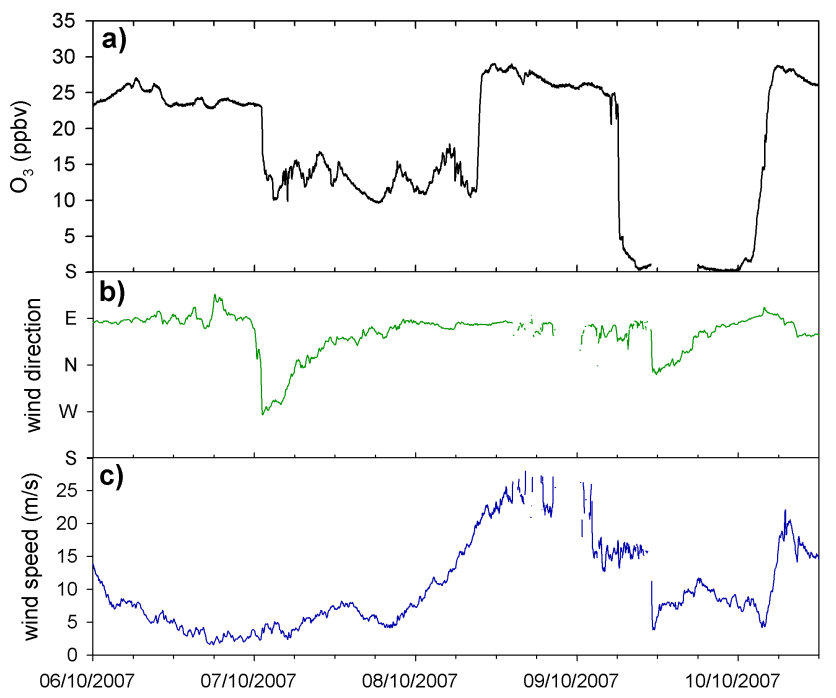

Fig. 3. Surface ozone and meteorological measurements from Halley. The date marks 00:00 for each day.

NOAA HYSPLIT MODEL

Backward trajectories ending at 0000 UTC 09 Oct 07 GDAS Meteorological Data

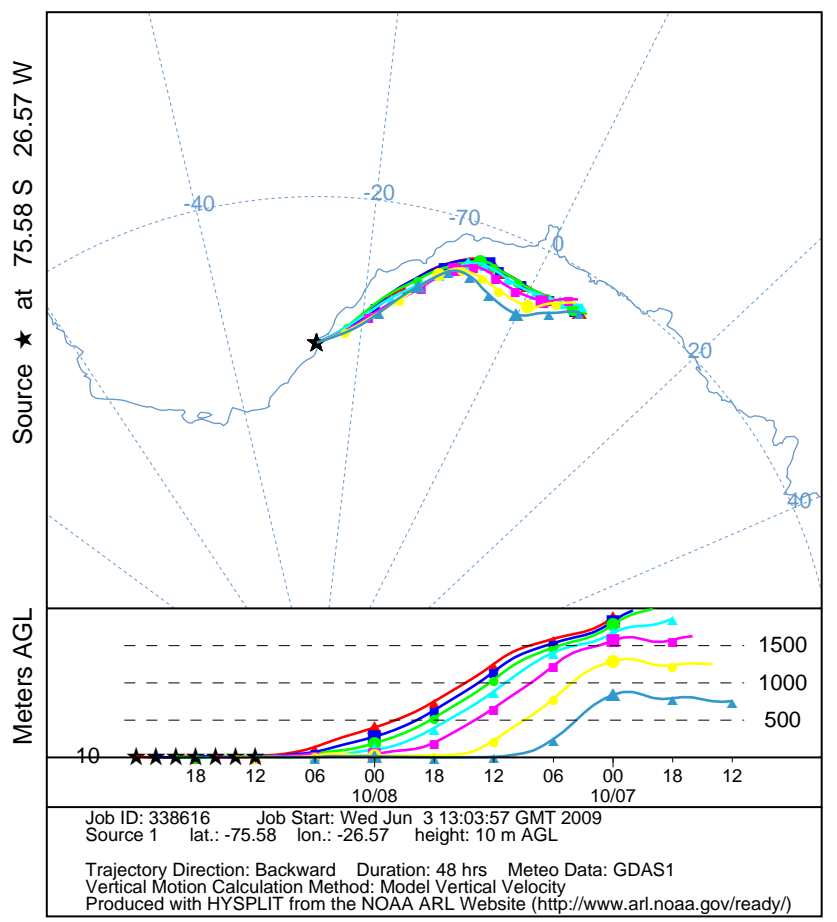

Fig. 4a. 2-day back trajectories arriving at Halley (marked with a star) on 8 October 2007 between noon and midnight. Top panel shows lat/lon plot and lower panel shows vertical profiles. All trajectories originate at height over the inland ice and have no contact with sea ice.
NOAA HYSPLIT MODEL

Backward trajectories ending at 18 UTC 09 Oct 07 GDAS Meteorological Data

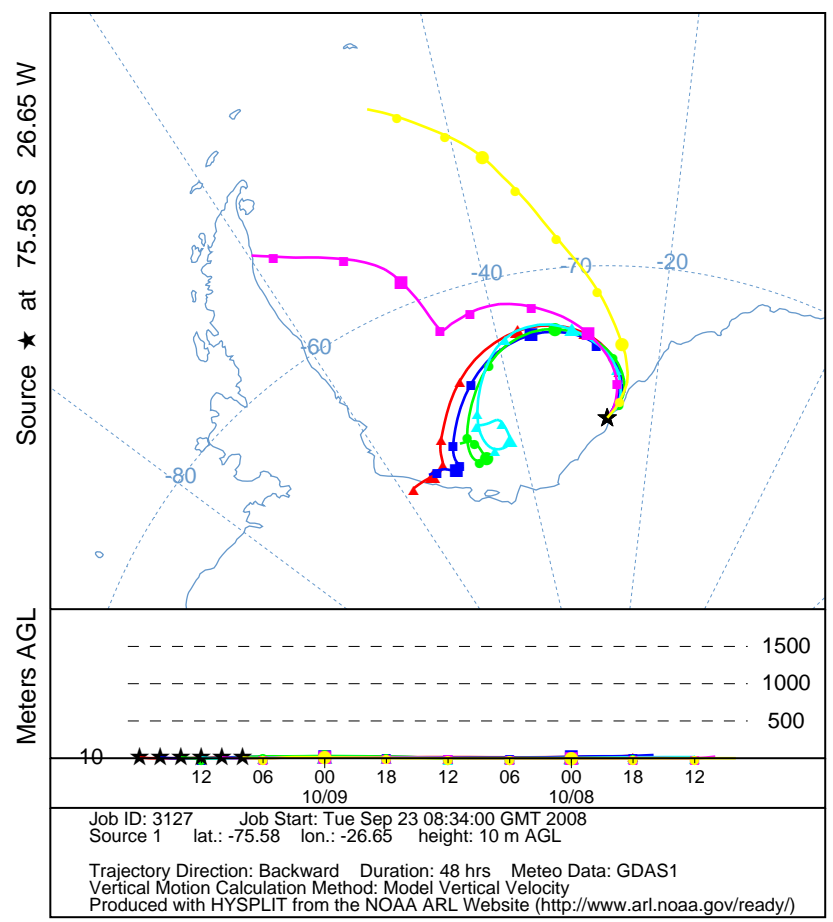

Fig. 4b. 2-day back trajectories arriving at Halley (marked with a star) on 9 October 2007 at 08:00 (yellow), 10:00 (pink), 12:00 (red), 14:00 (blue), 16:00 (green), and 18:00 (cyan). Although the lower panel suggests continuous "contact" with the sea ice, at the wind speeds encountered within the cyclonic system, no stratification would be possible and the entire boundary layer would have been mixed by the vigorous turbulence (see text for full discussion).

In order to explain these observations we carried out back trajectory analyses using the Hybrid Single-Particle Lagrangian Integrated Trajectory (HYSPLIT) model via the NASA ARL READY website (www.ready.noaa.gov/ready/ open/hysplit4.html) (Rolph, 2003; Draxler and Rolph, 2003). Two-day back trajectories were driven by meteorological fields from the NCEP Global Data Assimilation System (GDAS) model output. The trajectories were calculated using model vertical velocity at a resolution of $1^{\circ}$ by $1^{\circ}$, with an end point at the latitude and longitude of Halley and $10 \mathrm{~m}$ above ground level. Figure 4a shows that on the 8 October 2007, descending air arrived at Halley between noon and 22:00 which had originated over the inland ice and had had no contact with sea ice during the two days of approach. Consistent with this picture, surface ozone at Halley was present at background mixing ratios during this time period. The air parcel trajectories changed markedly during 9 October. Figure $4 \mathrm{~b}$ shows that the trajectories arriving from 08:00 onwards had all spent considerable time over the Weddell Sea sea ice zone. The lower panel shows the apparent height 
of the air parcels en route to Halley and suggests continuous "contact" with the sea ice during the previous two days. However, the model output must be interpreted with caution. The trajectories are "flat" because the air is neither descending nor ascending. As we will see later, under the wind speeds occurring over the Weddell Sea at this time, no vertical stratification within the boundary layer would be possible due to vigorous mixing from turbulence. Surface ozone mixing ratios, as shown in Fig. 3a, were significantly depleted by $08: 00$ on October 9th, and remained suppressed throughout the day. The termination of the depletion event is shown in Fig. 4c, as the air parcel trajectories move progressively away from the sea ice covered Weddell Sea. Consistent with the surface $\mathrm{O}_{3}$ observations, trajectories arriving at Halley at midnight and 02:00 $\mathrm{h}$ had travelled over the Weddell Sea. Recovery of the ODE began around 02:30 (Fig. 3a), and indeed, the air parcel trajectory arriving at Halley at 04:00 had originated away from the sea ice covered Weddell Sea. By 05:30 the ODE had terminated completely, and the back trajectories show once again that air arriving at Halley had originated over the inland ice.

The combination of these data shows us i) that the air depleted in ozone measured at Halley originated over the Weddell Sea sea ice zone, ii) that the enhanced $\mathrm{BrO}$ evident in SCIAMACHY data coincides with depleted surface ozone measurements made at Halley, and iii) the time that the low ozone air (and hence the cloud of elevated $\mathrm{BrO}$ ) arrived at Halley. Once we have pinned down the timing, we can use other measurements made at Halley to probe the meteorological conditions within the edge of the $\mathrm{BrO}$ cloud.

\subsection{Boundary layer height and stability}

As outlined earlier, the propagation of $\mathrm{BrO}$ within the bromine explosion reactions, and associated ozone depletion, are often associated with a stratified shallow boundary layer. We can therefore use information gathered at Halley to consider the height and stability of the boundary layer during the 9 October ODE. An acoustic radar, or sodar, is run on a routine basis at Halley. It provides qualitative information on the turbulent boundary layer by recording backscatter intensity of a vertically propagating acoustic pulse (Neff and Coulter, 1985). In particular, the sodar can provide information on the height of the boundary layer, that is, the height at which surface-generated turbulence becomes negligible (Culf, 1989). Going in to the storm of 8 October, the sodar showed that the top of the boundary layer was around $100 \mathrm{~m}$ above ground level; once the storm arrived, wind noise obliterated the acoustic signal, and it was no longer possible to estimate boundary layer depth via this method. Although there is no direct data on boundary layer depth during the storm itself, the increase in surface stress (from the increase in wind) will tend to increase the depth of a well mixed boundary layer (Zilitinkevich and Mironov 1996). It is reasonable to assume
NOAA HYSPLIT MODEL

Backward trajectories ending at 08 UTC 10 Oct 07 GDAS Meteorological Data

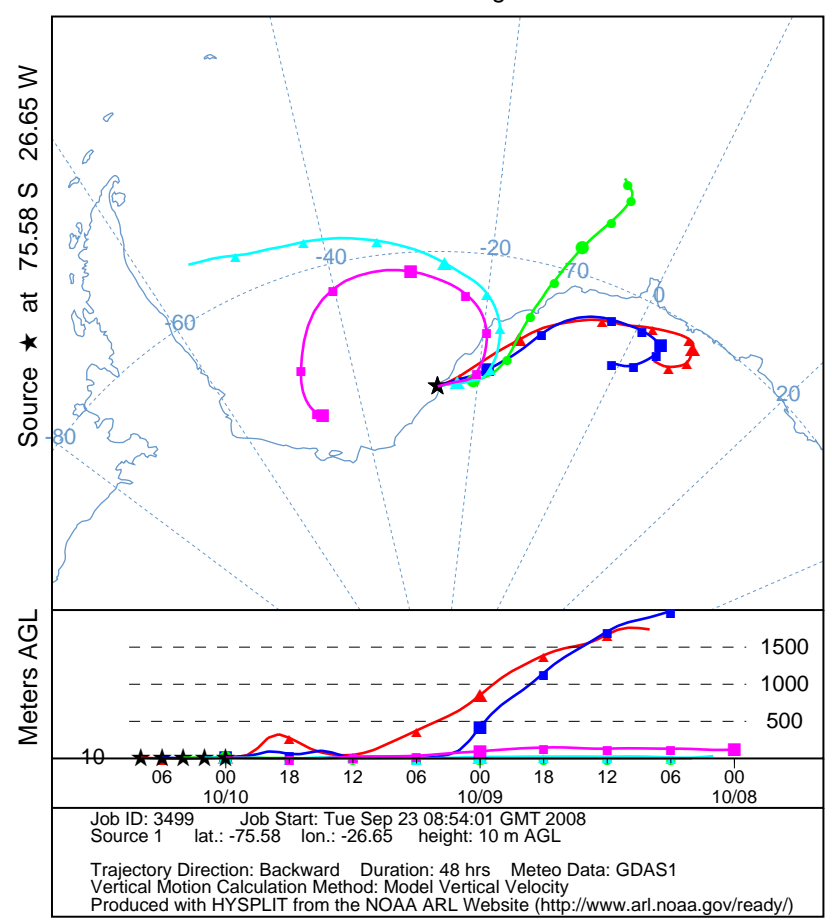

Fig. 4c. 2-day back trajectories arriving at Halley (marked with a star) on 10 October 2007 at 00:00 (pink), 02:00 (cyan), 04:00 (green), 06:00 (red), and 08:00 (blue). Recovery of the ODE is evident from $\sim 0200$ as the trajectories move away from the Weddell Sea sea ice zone. By 05:30 no surface ozone depletion is evident at Halley, and indeed, the trajectories arriving at Halley after this time show, once again, descending air that has originated over the inland ice.

that the boundary layer height on $8 / 9$ October was at least $100 \mathrm{~m}$.

Air temperature profiles from a $32 \mathrm{~m}$ mast show the atmosphere to be un-stratified prior to the event. With the vigorous shear-driven mixing near the surface, this lack of stratification was maintained throughout the storm of 8 to 9 October, with zero temperature gradient observed between the mast sensors.

\subsection{Blowing snow}

Wind stress acting over snow tends to transport ice/snow particles. Above a threshold speed of $\sim 8 \mathrm{~ms}^{-1}$ (measured at $10 \mathrm{~m}$ ), particles can be dislodged from their resting place on the surface, bounce into the airstream, and gain momentum from the wind (Mann et al., 2000). The accelerated particles then dislodge other particles in a cascade. For winds within the $8 \mathrm{~ms}^{-1}$ to $12 \mathrm{~ms}^{-1}$ range, snow transport is exclusively due to this "saltation" process, and remain in a layer $\sim 10 \mathrm{~cm}$ deep above the surface. Above $\sim 12 \mathrm{~ms}^{-1}$, the turbulence 
in the atmosphere generates sufficiently vigorous diffusion, that particles are lofted out of the saltation layer. It is at this level that "blowing snow" is reported, observed as a reduction in visibility, and measured as particles at and above $1 \mathrm{~m}$. As wind speeds increase above $12 \mathrm{~ms}^{-1}$, the total volume of snow above a unit area increases. At a given height, the particle number density for all size bins increases but with a small mode shift towards larger particles. Given the wind speeds recorded at Halley, blowing snow would therefore be expected. Weather observations are made at Halley every $3 \mathrm{~h}$ by the meteorological observer and amongst the information recorded is the amount of blowing snow. On 9 October, during the ODE, the weather logs do indeed report considerable amounts of blowing snow.

\subsection{Snow salinity}

Measurements of surface snow were made at Halley on various days after the storm of 8/9 October. On 10,12, 13 and 14 October, accuvettes were pushed directly into the wall of mini-snowpits, three samples being taken on each occasion at $2 \mathrm{~cm}$ depth. On 19 October, a deeper snow pit was sampled, again, using accuvettes pushed directly into the wall of the pit. All samples were stored frozen, and returned to the UK for analysis using an ion chromatograph (IC). Figure 5a shows the concentration of bromide in snow at $2 \mathrm{~cm}$ depth on 10, 12, 13, 14 October (averages from the three samples taken on each occasion) and on 19 October. A rapid decline in bromide concentration is clear. The hourly weather logs from Halley report snow fall over this time period on numerous occasions, so this decline can be accounted for by burial by subsequent snowfall. No samples were taken before 10 October as sampling was done in response to the storm. However, information on bromide concentrations prior to this period can be gained from Fig. $5 \mathrm{~b}$ which shows the bromide profile derived from the deeper snow pit that was sampled on 19 October. Clearly the bromide peak has been buried to a depth of $\sim 6 \mathrm{~cm}$. It shows, further, that the bromide concentration of snow during the 8/9 October storm was roughly a factor 5 higher than the background concentration at this time of the year.

From the measurements made at Halley we can therefore deduce that, within the edge of the enhanced $\mathrm{BrO}$ cloud, the boundary layer was very well mixed, extended to at least $100 \mathrm{~m}$ above the ground, and contained considerable amounts of blowing snow. The snow pit data suggest that this blowing snow had an enhanced salinity, with concentrations several times higher than the normal background.

\section{Probing the regional observations}

To probe the regional scale situation, we use SCIAMACHY images (retrieved from SCIAMACHY nadir measurements) achieved during individual satellite swaths, as opposed to the
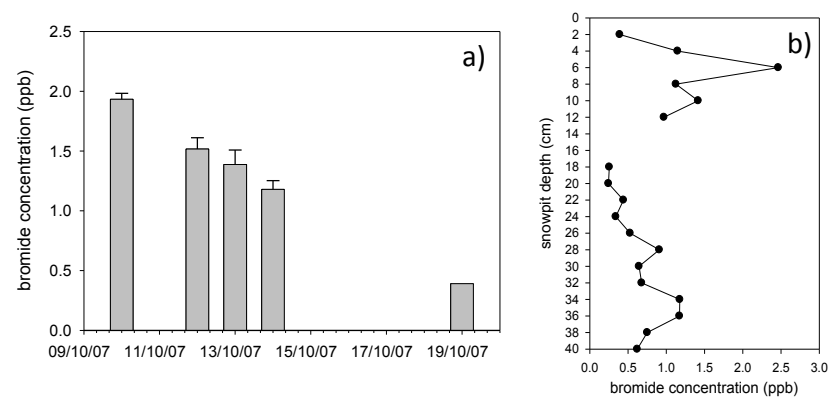

Fig. 5. (a) Concentration of bromide in surface snow sampled on various days following the 8/9 October storm; (b) Concentration of bromide in a snow pit sampled on 19 October 2007. By this time, the peak in bromide concentration driven by the $8 / 9$ October storm has been buried to a depth of $\sim 6 \mathrm{~cm}$.

composite image shown in Fig. 2b. Although coverage is limited by the satellite orbit, there is a considerable increase in the amount of information available on the days of interest. In particular, it is possible to consider the speed at which changes in $\mathrm{BrO}$ column density occurs. The swaths are recorded at roughly $11 / 2$ hour intervals, the time given being the overpass time (UT) at $75^{\circ} \mathrm{S}$ for the individual orbits. As the satellite moves quickly, the time difference along one orbit is very small over the region of interest.

To provide information on the mesoscale meteorological systems at play we use charts from the European Centre for Medium-range Weather Forecasts (ECMWF) operational numerical weather prediction system. The latter have been used previously in a study of ODEs at Halley (Jones et al., 2006), and are known to be of high quality even in the Antarctic coastal zone (King, 2003). Specifically, we consider the 10$\mathrm{m}$ wind speeds (both as vectors and contours).

On 8 October, the ECMWF 10-m wind vector charts show the presence of a strong cyclonic event centred over the Weddell Sea (Fig. 6a and b). By noon the storm encompasses the entire Weddell Sea, with winds in excess of $16 \mathrm{~ms}^{-1}$. Along the coast by Halley wind speeds are higher due to the effect of enhanced katabatics. ECMWF data show that wind speeds in this area are in excess of $24 \mathrm{~ms}^{-1}$, a result that is supported by ground-based measurements at Halley station. Figure 7a, $\mathrm{b}$, and $\mathrm{c}$ show BrO column density from individual SCIAMACHY swaths also for 8 October 2007, taken at intervals of roughly $11 / 2 \mathrm{~h}$. Within the available spatial coverage it is possible to say the following: at 09:06 (Fig. 7a) there appears to have been a limited patch of enhanced $\mathrm{BrO}$ over the Filchner ice shelf $\left(\sim 80^{\circ} \mathrm{S}\right)$. The fact that the rest of the swath shows background levels of $\mathrm{BrO}$ suggests that this enhanced $\mathrm{BrO}$ is isolated from any other area of high $\mathrm{BrO}$ that might have been present within the Weddell Sea area. $11 / 2 \mathrm{~h}$ later (Fig. 7b), a strip of enhanced $\mathrm{BrO}$ extends from the Filchner up to the furthest extent of the satellite swath at around $68^{\circ} \mathrm{S}$ (a distance of over $1400 \mathrm{~km}$ ). Indeed, the enhanced $\mathrm{BrO}$ is 

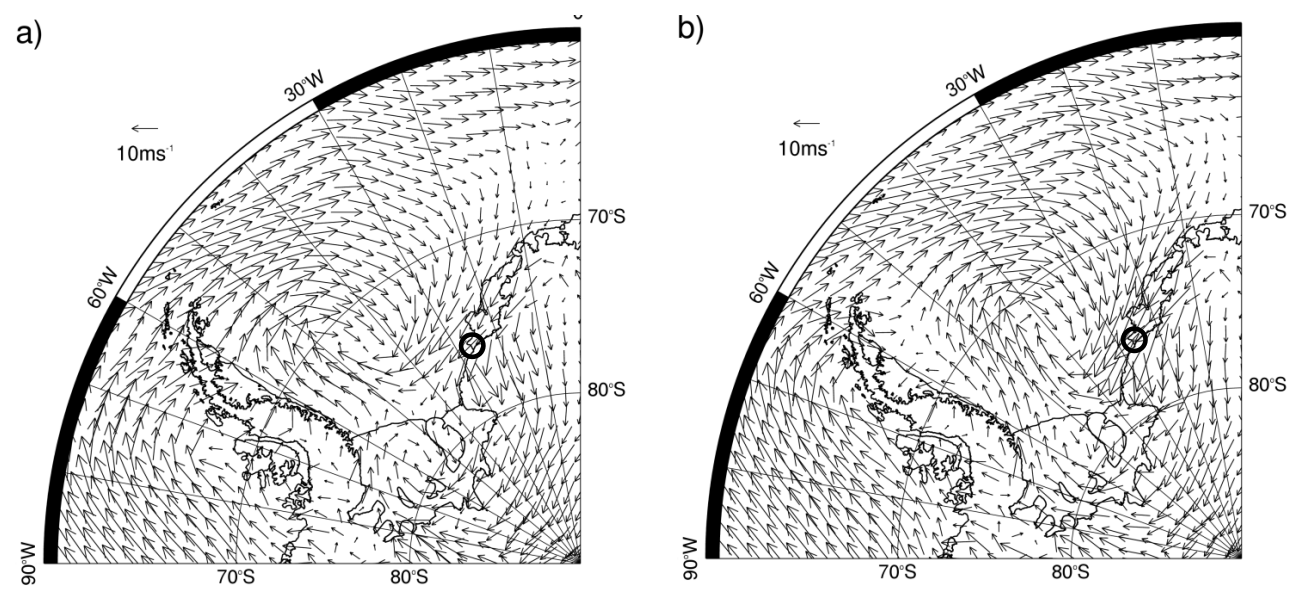

Fig. 6. ECMWF chart showing 10-m wind vectors on 8 October 2007 at (a) 06:00 and (b) 12:00. The position of Halley is shown by the open circle.
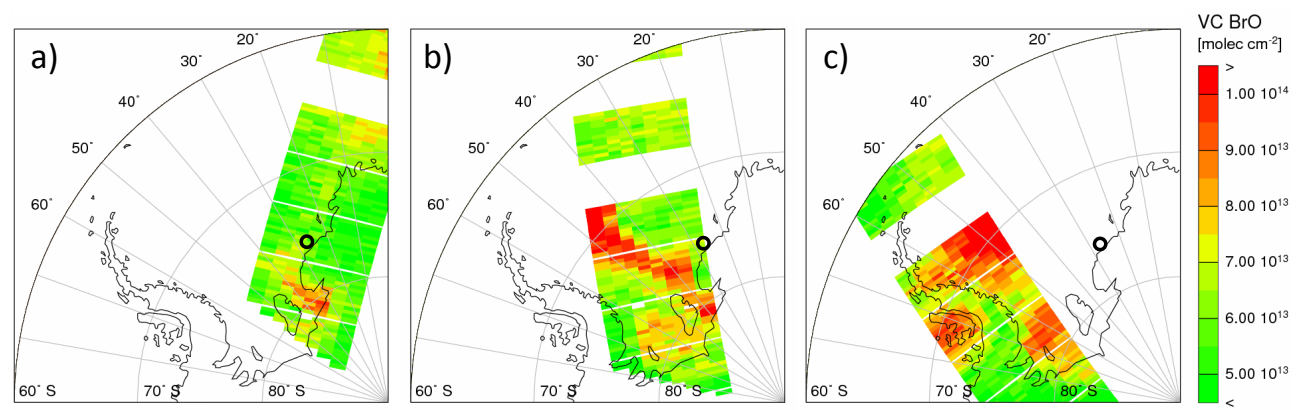

Fig. 7. BrO column densities across the Weddell Sea region of Antarctica on 8 October 2007 at (a) 09:06 a.m., (b) 10:46 a.m., (c) 12:27 p.m. The position of Halley is shown by the open circle.

likely to be present within areas that were not accessible to the satellite at this time; this is evident from the high levels of $\mathrm{BrO}$ that are present right at the most northerly edge of the swath image. Figure $7 \mathrm{c}$ shows the $\mathrm{BrO}$ column density around noon, and that the columns are enhanced within the western area of the Weddell Sea.

The question then arises, whether the $\mathrm{BrO}$ is transported, or has evolved in situ. To address this, we focus on the sector that lies between the $40^{\circ}$ and $50^{\circ} \mathrm{W}$ longitude lines. In Fig. 7a, we see that the most northerly swath data within this sector show BrO columns of below $6.5 \times 10^{13}$ molec $\mathrm{cm}^{-2}$. By 10:46 (Fig. 7b), column densities in this area are around $9 \times 10^{13} \mathrm{molec} \mathrm{cm}^{-2}$. Given that there is a patch of enhanced $\mathrm{BrO}$ apparent over the Filchner Ice Shelf around 09:06 a.m. (Fig. 7a), could this be a source region, with $\mathrm{BrO}$ being transported north along the wind vectors? The answer is that at the wind speeds in this area at this time (around $12 \mathrm{~ms}^{-2}$ ), transport alone could have moved enhanced $\mathrm{BrO}$ only $65 \mathrm{~km}$ in the $11 / 2 \mathrm{~h}$ between the satellite swaths. This is insufficient to account for the observations of Fig. 7b. The swath images strongly suggest in situ generation/propagation.
Interestingly, Fig. $7 \mathrm{~b}$ shows a tongue of enhanced $\mathrm{BrO}$ that effectively spans the $40^{\circ}$ to $50^{\circ} \mathrm{W}$ longitude region of the Weddell Sea. The equivalent plot, but now of noon 10-m wind speed contours (Fig. 8), emphasises that this region is the windiest over the Weddell Sea, with wind speeds over $16 \mathrm{~ms}^{-2}$. We examine the link to wind speed below.

On 9 October, the storm over the Weddell Sea was still raging (see Fig. 9a and b). The cloud of BrO had extended such that it covered the majority of the Weddell Sea, and column amounts up to $16 \times 10^{13}$ molec $\mathrm{cm}^{-2}$ were evident over significant areas of the sea ice zone (Fig. 10). The cyclone was moving eastward, such that by 06:00, it had reached Halley. The enhanced katabatics found at the edge of the cyclone had moved inland, and the winds at Halley were those of the cyclone's edge, i.e. around $15 \mathrm{~ms}^{-2}$. Again, the wind speeds at Halley (given in Fig. 3b) provide important ground truth for the ECMWF data. These events show that the BrO cloud over the Weddell Sea had grown considerably under meteorological conditions of high wind speeds. The notion of the bromine explosion (and ozone depletion events) requiring low wind speeds and a stable boundary layer in order to propagate are clearly not supported by these observations. 


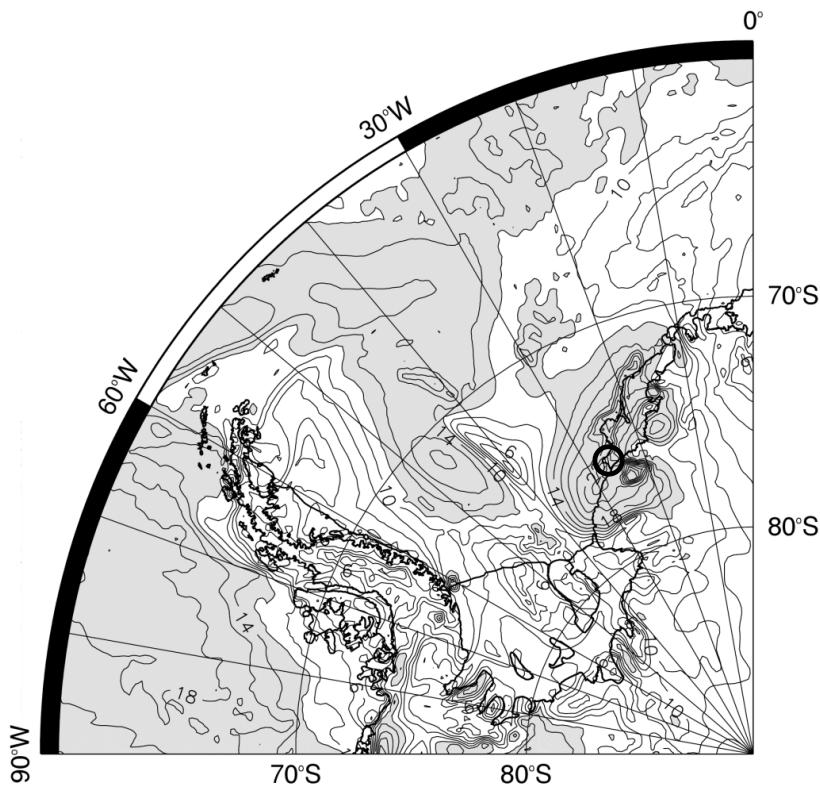

Fig. 8. ECMWF chart showing contours of 10-m wind speeds at 12:00 on 8 October 2007. Contours are shown at $4 \mathrm{~ms}^{-1}$ intervals; areas with wind speeds of over $12 \mathrm{~ms}^{-1}$ are highlighted in grey. Note the wind speed maximum over the Weddell Sea is co-located with the $\mathrm{BrO}$ column density maximum shown in Fig. 7b. The position of Halley is shown by the open circle.

\subsection{Discussion}

Yang et al. (2008) use a three-dimensional numerical model to investigate the role of snow on sea ice and its potential, via blowing snow, to be a source of sea salt aerosol and subsequently of bromine. Based upon specific conditions of wind speed and relative humidity, they calculate the total sea salt aerosol production as well as its size distribution. They derive a bromine source based on the bromine depletion factor - the amount by which aerosol bromide is depleted relative to bulk sea water - which is dependent on the aerosol size distribution. They assume that once an aerosol particle has formed it immediately releases bromine in the form of $\mathrm{Br}_{2}$. They find that under high wind conditions, ozone is entrained into the model boundary layer from the upper troposphere such that $\mathrm{O}_{3}$ mixing ratios remain at at least 10 ppbv. Complete BL ozone destruction is only achieved under stable conditions where stratification prevents downward mixing of ozone from aloft. We present observational evidence from Antarctica that is consistent with an association between blowing snow and ozone depletion/enhanced BrO.

An obvious question at this stage is the capability of the satellite instrument to "see" into blowing snow. i.e. is it possible that it can measure $\mathrm{BrO}$ within blowing snow, or is it more likely that it is measuring $\mathrm{BrO}$ that is located above the blowing snow layer? Experience from ground-based ob- servations suggest that a good signal can be achieved with long light-paths under blowing snow conditions. However, from satellites, it can be expected that the blowing snow will reflect a proportion of the photons, and the penetration into blowing snow of the remaining photons has not previously been assessed. The analogous snowpack modelling study of Lee-Taylor and Madronich (2002) outlined in Sect. 1. is also relevant here, as, assuming that $\mathrm{BrO}$ is present within the blowing snow, it is reasonable to expect to see at least part of it from the satellite, the reduced light penetration being partly offset by the enhanced light path. More quantitative statements would have to rely on radiative transfer calculations within blowing snow itself which go beyond the scope of this paper. We note, however, that the association between high $\mathrm{BrO}$ events and blowing snow is also apparent from earlier ground-based studies (Kreher et al., 1998; Frießet al., 2004). We therefore assume that this relationship exists, and use the observations presented in this paper to explore whether the role played by blowing snow is indirect (i.e. via aerosol) or whether there might be an alternative route for bromine production, namely that the blowing snow itself might be a direct halogen source, and that the additional step of aerosol production is not essential for the argument.

In order to achieve and sustain an ozone depletion event it is necessary to generate and re-cycle Br radicals. As shown in Fig. 1, this is a multi-phase process, requiring contact between the gaseous and the condensed phases. Based solely on the premise that such contact is a prerequisite to any uptake and therefore reaction, we explore here the environmental conditions that favour contact between trace gases and blowing snow. Specifically, we model certain parameters that would influence the probability of contact between gaseous and condensed phase molecules, and the way in which they vary with wind speed. We consider only the likelihood of contact and do not account for any subsequent uptake or reaction probabilities. The question of salinity is discussed below. Here we focus on two parameters, namely boundary layer height and snow surface area. We take a simplified approach in order to gain qualitative information rather than strict quantitative conclusions, which would go beyond the scope of this present paper. For example, we do not consider the issue of "effective surface area" - the fact that for heterogeneously-distributed salts, it is not the total surface area that matters, but the surface area of substrate with sufficient salinity. Instead we assume that sufficient salinity is available and that it is evenly distributed across the snow surface, i.e. that the snow surface area and the effective snow surface area are one and the same thing. Neither do we consider the $\mathrm{pH}$ of the substrate and the mechanism by which a sufficiently low $\mathrm{pH}$ is achieved to enable reactions to proceed (e.g. Simpson et al., 2007).

A qualitative model of the effect of blowing snow can be built by combining the contribution from the height of the boundary layer, $h_{z}$, with the available snow surface area within blowing snow. Neither of these terms is accurately 

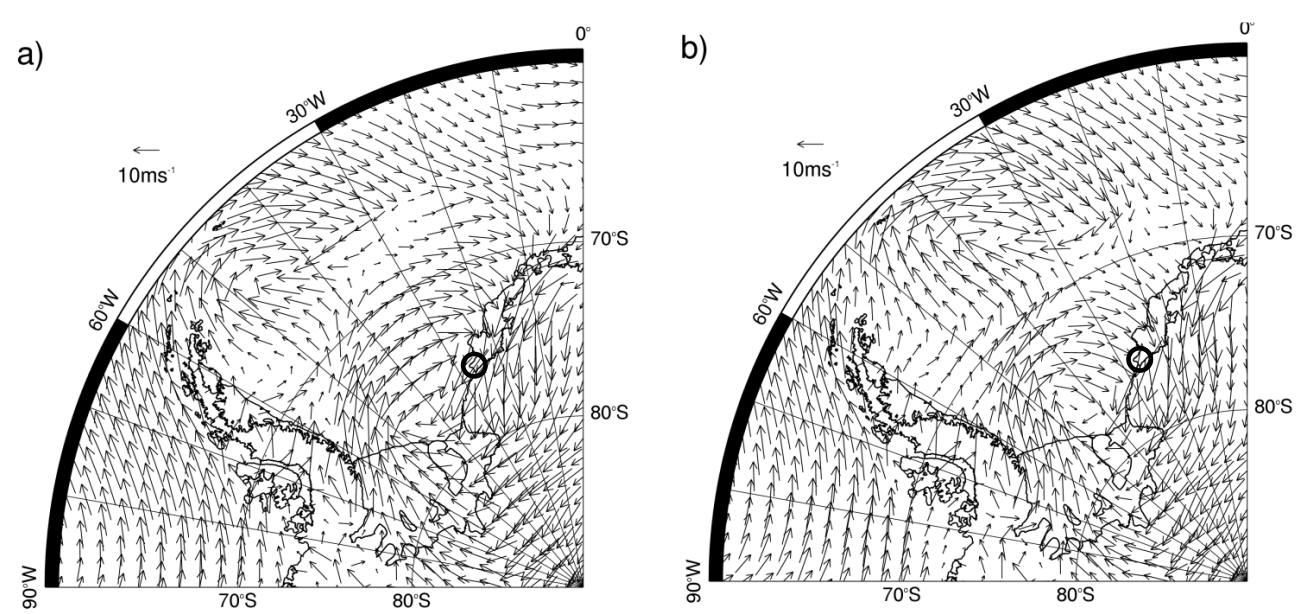

Fig. 9. ECMWF chart showing 10-m wind vectors on 9 October 2007 at (a) 06:00 and (b) 12:00. The position of Halley is shown by the open circle.
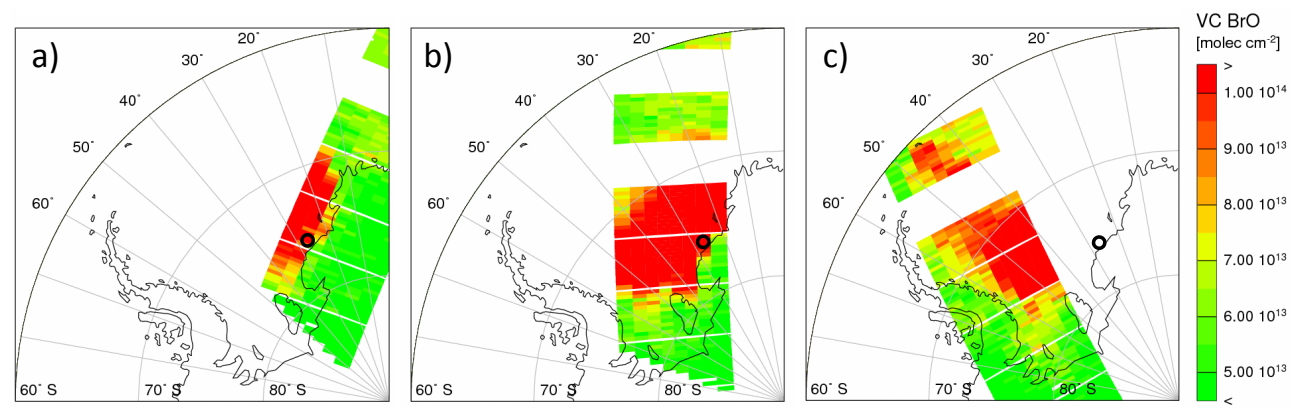

Fig. 10. BrO column densities across the Weddell Sea region of Antarctica on 9 October 2007 at (a) 08:35 a.m., (b) 10:15 a.m., (c) 11:56 a.m. The position of Halley is shown by the open circle.

parameterised in the literature, and their relative influence on rates of atmospheric chemical reactions is even less understood. The model can, however, offer a conceptual framework to explore these issues.

$h_{z}$, as measured by acoustic radar, is relatively small in polar regions compared to mid-latitudes (Anderson and Neff, 2007), extending to $100 \mathrm{~m}$ at moderate wind speeds and reducing to $10 \mathrm{~m}$ or even less in near calm conditions. Neff et al. (2008) suggest that $h_{z}$ is linearly related to surface stress, $u_{*}$. We propose a simple function which describes the tendency for $h_{z}$ to increase with wind speed, assuming that $u_{*}$ is proportional to the $10-\mathrm{m}$ wind speed, $U_{10}$. We note that the shallowest boundary layers observed at Halley (a flat homogenous terrain with similarities to a plane of sea-ice) with sodar or tower are $\sim 10 \mathrm{~m}$. These occur under near calm conditions. When $10-\mathrm{m}$ winds are of the order of $10 \mathrm{~ms}^{-1}$, the Halley sodar shows turbulence $\sim 60 \mathrm{~m}$. A highly simplified parameterisation of $\mathrm{h}_{z}$ would therefore be:

$h_{z}=5 U_{10}+10$.
We do not suggest this is a suitable scheme for modeling purposes, but the function is sufficient to indicate the essence of the bi-modal nature of ozone depletion as a function of wind speed.

The available surface area of ice within the blowing snow can be estimated from a parameterisation of the number density, $N_{D}$, which itself is a function of wind speed, $U$, height, $\mathrm{z}$, and particle radius, $r$.

$N_{D}$ can be approximated from Halley measurements using two functions described in Mann et al. (2000). First, the function for total particle number at a given height and wind speed, $N_{\text {tot }}(z, U)$ and second, the function for a typical particle size distribution as a function of height, $N_{\mathrm{PSD}}(z, r)$. Mann (2000) describes $N_{\mathrm{PSD}}(z, r)$ as having a maximum in the $20-50 \mu \mathrm{m}$ range, with the mode of the distribution decreasing with increasing height. The total number of particles of a given radius at a given height and for a given wind speed, $N_{D}(z, U, r)$, is then a convolution of these functions:

$N_{D}(z, U, r)=N_{\text {tot }}(z, U) \times N_{\mathrm{PSD}}(z, r)$ 
i.e. $N_{\text {tot }}$ is the sum over all radii, and $N_{\mathrm{PSD}}$ is invariant with wind speed.

Measurements of the total number of snow particles at $8 \mathrm{~m}$ as a function of $U$ are given in Mann et al. (2000), from which we derive an empirical function by least squares fit:

$N_{\text {tot }}(8, U)=10^{0.08 U+1.20 U^{1 / 2}}$

$N_{\text {tot }}(z, U)$ for any $z$ is then

$N_{\text {tot }}(z, U)=N_{\text {tot }}(8, U)\left(\frac{z}{8}\right)^{\frac{-W_{f s}}{\kappa u_{*}}}$

where $\kappa=0.4$ is the von Kármán constant and $-W_{f s}$ is the estimated mean fall speed of the particles. Following Mann et al. (2000), we used $W_{f s}=0.12 \mathrm{~ms}^{-1}$, which will add a bias by over-estimating the settling speed of the smaller particles. $u_{*}$ is estimated from the $10-\mathrm{m}$ wind speed assuming surface similarity under neutral stratification:

$\frac{\kappa U}{u_{*}}=\ln \left(\frac{z}{z_{0}}\right)$

where $z_{0}$ is the roughness length of the surface, taken as $5 \times 10^{-5} \mathrm{~m}$ (King and Anderson, 1994), and setting $z=10$.

The particle size distribution, $N_{\mathrm{PSD}}(z, r)$ is given in Mann et al. (2000) for a known mean particle radius, $\bar{r}$ :

$N_{\mathrm{PSD}}(z, r)=\frac{e^{-r / \beta} r^{\alpha-1}}{\beta^{\alpha} \Gamma(\alpha)}$

where $\beta=\bar{r} / \alpha$, and $\Gamma(\alpha)$ is the Gamma function. Measurements give $\alpha=1.8$. Although $\bar{r}$ is a function of both $z$ and $U$, large variability in the data only allow an estimate of $\bar{r}(z)$ for all blowing snow measurements, and this will again bias the final functions. Taking mean values from Mann et al. (2000) gives:

$\bar{r}=10^{-5} e^{z / 10}$

Combining Eqs. (6) and (7) gives $N_{\mathrm{PSD}}(z, r)$.

Equation (4) gives the total number of particles for a given height and wind speed. This set of equations (Eqs. 3, 5 and $6)$ therefore gives an estimate of $N_{D}$. The surface area contribution $A_{b s}\left(z, U_{10}, r\right)$ for any given radius, $r$, is given by assuming spherical particles:

$A_{b s}\left(z, U_{10}\right)=4 \pi \int_{0}^{\infty} r^{2} N_{D}\left(z, U_{10}, r\right) d r$.

The unit of $A_{b s}\left(z, U_{10}, r\right)$ is surface area per unit volume, that is, $\mathrm{m}^{-1}$. Figure 11a is a contour plot of the contribution to total snow particle surface area as a function of particle radius and height for $U_{10}=20 \mathrm{~ms}^{-1}$. It clearly shows that there is very little contribution to blowing snow surface area for $z>10 \mathrm{~m}$, and that the radius of maximum contribution decreases with increase in $z$. To estimate total ice/snow surface
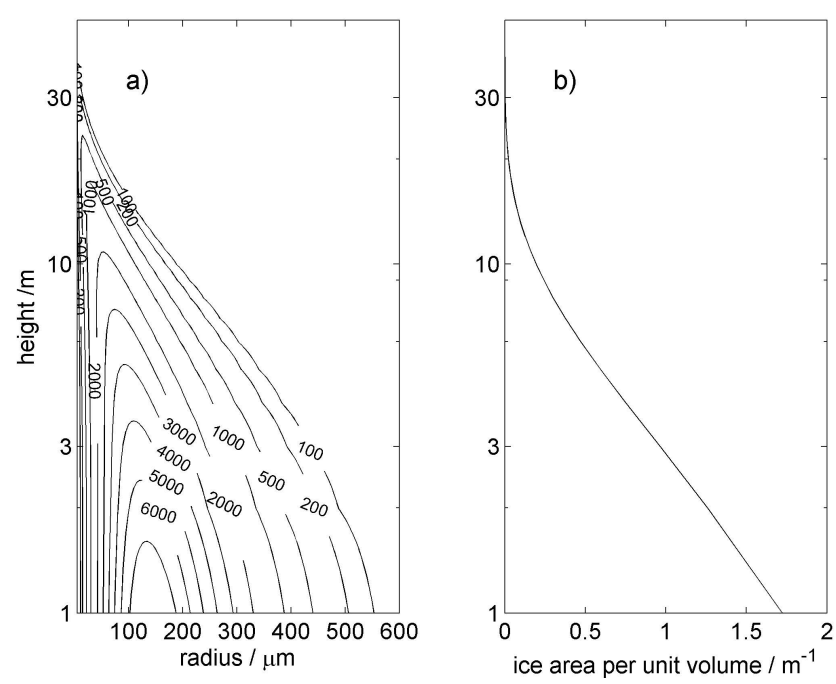

Fig. 11. (a) The surface area of ice in blowing snow at $U_{10}=20 \mathrm{~ms}^{-1}$, as a function of particle radius and height. Note that height is on a log axis and that the contour units are ice surface area $\left(\mathrm{m}^{2}\right)$ per unit volume $\left(\mathrm{m}^{-3}\right)$ per metre radius $\left(\mathrm{m}^{-1}\right)$; (b) The total surface area of ice in blowing snow at $U_{10}=20 \mathrm{~ms}^{-1}$ within a unit volume at height $z$.

area within a unit volume at height $z$, the function can be integrated numerically from, say, $r=0$ to $1000 \mu \mathrm{m}$ with steps of $\delta z$ sufficiently small to capture the form of the function. This is shown in Fig. 11b. It demonstrates that, when 10-m wind speeds are $20 \mathrm{~ms}^{-1}$, the majority of blowing snow surface area is found in the lowest layers of the boundary layer.

The total surface area of snow available for air-ice interaction, $A_{\text {tot }}$, includes both the ground-based snowpack surface and the blowing snow component. For a unit snowpack surface area, $A_{\text {tot }}$ can be derived:

$A_{\mathrm{tot}}=1+\int_{0}^{\infty} A_{b s} d z$

This approach ignores any activity that might occur within the firn itself, and assumes that in the non-blowing snow situation all heterogenous reactions occur on the uppermost face of the snowpack. Although such an approach introduces some bias, the relative importance of enhanced snow surface area itself as opposed to enhanced ventilation (i.e. enhanced movement of air past snow surfaces as induced by increasing wind speed) is not clear at present.

We have thus now derived the equations necessary to describe the two key environmental parameters that influence the degree of contact between gaseous and condensed phases (i.e. the suspended condensed phase and ground-based snowpack surface) and the way in which they vary with wind speed. The variation of boundary layer height with wind speed is shown graphically in Fig. 12a with a linear relationship with wind speed. That of the snow surface area within blowing snow is shown in Fig. $12 \mathrm{~b}$, assuming a $1 \mathrm{~m}^{2} / \mathrm{m}^{2}$ 

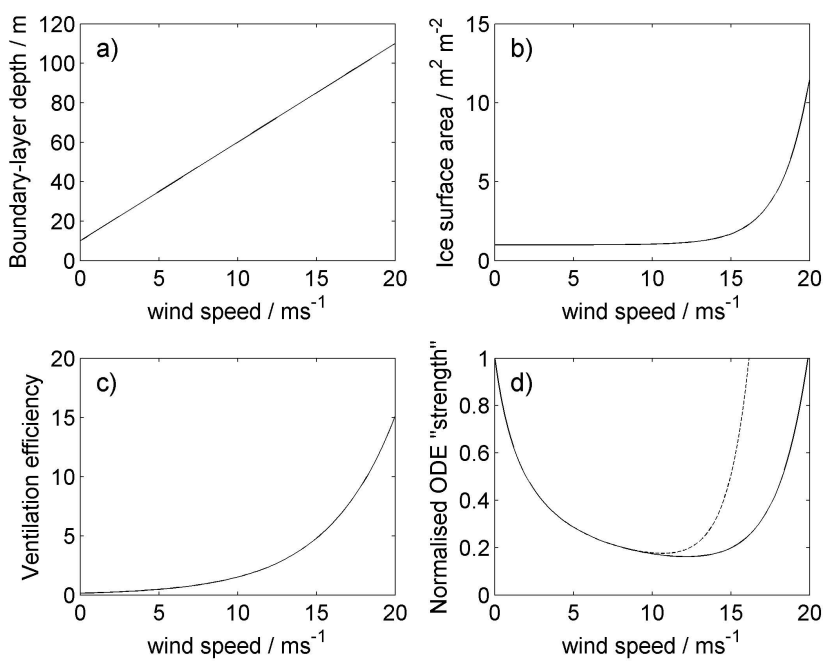

Fig. 12. (a) The variation of boundary layer height with wind speed; (b) The variation of snow surface area within blowing snow according to wind speed; (c) The enhancement function that accounts for the influence of ventilation according to wind speed; (d) the potential for boundary layer ozone depletion found by dividing the data from (b) by (a) (the dashed line, accounting for ventilation, is b.c/a). See discussion.

availability at zero wind speed (i.e. solely the ground-based snowpack). As wind speeds increase, blowing snow is generated, thus increasing the surface area of snow per unit area of earth surface. At high wind speeds, the snow surface area increases exponentially.

The probability of contact between a gaseous and a condensed phase is determined by the availability of both. For trace gases with a ground-based source, their concentration increases with decreasing boundary layer height. The probability of contact can therefore be described as:

contact $\propto \frac{\text { snow surface }}{\text { boundary layer height }}$

Assuming that the snow surface is sufficiently enhanced in $\mathrm{Br}^{-}$and of an appropriate $\mathrm{pH}$, then one can propose that

degree of ozone depletion $\propto \frac{\text { snow surface area }}{\text { boundary layer height }}$

However, the actual contact between a suspended snow particle and a gaseous molecule is enhanced by ventilation, which is achieved both by the particle fall rate and by local turbulence around the particle. Full calculation of particle ventilation is highly complex and goes beyond the scope of this paper; instead, we employ a proxy derived from the calculation of ice particle evaporation rate within blowing snow in Déry and Taylor (1996). Their model study implies that rate of sublimation within the blowing snow, $\mathrm{Q}_{\text {subl }}$, is mostly dependent upon wind speed, and an empirical function can be extracted,

$Q_{\text {subl }}=10^{0.1 U_{10}-2.3}$ which gives the cumulative sublimation rate in $\mathrm{g} \mathrm{m}^{-2} \mathrm{~s}^{-1}$ for a column of blowing snow over a unit area; units from Déry and Taylor (1996) have been retained. Using this as a proxy for any air-ice interaction within blowing snow, a ventilation enhancement, $V_{\mathrm{enh}}$, is given by

$V_{\text {enh }}\left(U_{10}\right)=\frac{Q_{\text {subl }}\left(U_{10}\right)}{Q_{\text {subl }}(8)}$

so that $V_{\mathrm{enh}}=1$ for $U_{10}=8 \mathrm{~ms}^{-1}$, that is, the threshold wind speed for the onset of blowing snow. This enhancement function is shown in Fig. 12c. The enhanced total surface area, $A_{\text {enh }}$, for air-ice interaction therefore becomes

$A_{\text {enh }}=1+V_{\mathrm{enh}} A_{b s}$.

Figure $12 \mathrm{~d}$ shows how the potential for boundary layer ozone depletion varies with wind speed both with and without accounting for ventilation. The first thing to note is that there are two maxima. The first arises at very low wind speeds. This is consistent with reports that ODEs are frequently observed under conditions of a stable shallow boundary layer when reactants are constrained into a small volume of the atmosphere. The second maximum arises at high wind speeds. It is driven in this analysis by the additional snow surface area derived from blowing snow, an effect that is considerably exacerbated when ventilation is taken into account (the dashed line). This result is consistent with the observations reported here, that $\mathrm{BrO}$ enhancement and associated ozone loss can also occur under conditions of high wind speed and turbulent mixing within the boundary layer.

An important remaining question for our analysis of this event, however, concerns the salinity of the wind-blown snow. It is known that within the sea ice zone, snow lying on sea ice has an enhanced salinity. Blowing snow that originates within the sea ice zone is therefore likely also to be saline. We argue, based on the satellite $\mathrm{BrO}$ data, that the region around Halley was within the boundary layer zone where bromine was actively being propagated, possibly also initiated. To be consistent with this, the blowing snow at Halley during the event would need to be saline. The results from both the surface snow and snow-pit sampling presented in Fig. 5 are consistent with this idea, but are only part of the story. It is important to note that these are bulk concentrations measured once the snow has melted. The results say nothing about the distribution, and hence the "availability", of bromide within/on the snow particles. For example, the influence of a specific bulk bromide concentration distributed evenly throughout a snow particle would be very different to one distributed heterogeneously, with patches of high concentration interspersed in a non-saline background. Given the distance from the coast, the concentration of bromide in blowing snow at Halley is likely to be substantially lower than over the sea ice zone as dilution would occur by mixing with continental snow. The relative change in snowpack bromide observed at Halley, however, reflects the wider picture of significantly more airborne salinity associated with 
the storm than under background conditions. Whether this change is driven by deposition of salty snow, or by subsequent deposition of aerosol cannot be resolved from these particular observations. However, other studies at Halley have shown that sharp spikes in snowpack impurities such as nitrate and sea salt (sodium) are associated with specific snowfall deposition events (e.g. Jones et al. 2008; Wolff et al., 2008). The observations also open the possibility of enhanced initiation processes within the snowpack.

A further question relates to the $\mathrm{pH}$ of the blowing snow. However, although it is straightforward to melt snow samples and derive a $\mathrm{pH}$, what is relevant in this case is the $\mathrm{pH}$ of the surface, and not of the bulk. Deriving the $\mathrm{pH}$ of a quasiliquid surface is far from trivial, and an assessment was not possible during the work reported here.

The notion that blowing snow could be a direct source of bromine and hence of ozone destruction thus appears to be consistent with observations and the analysis conducted here provides some insight into why ODEs are observed under specific wind conditions (i.e. either low wind speeds or high).

We can now consider the ideas of Yang et al. (2008) within the framework of the observations presented here. The model of Yang et al. assumed that each blowing snow particle would contain a sea salt aerosol nucleus, and that snow particles would sublime, thus generating naked aerosol. We have shown that at the wind speeds that occurred over the Weddell Sea on 8 and 9 October (ground-truthed by observations at Halley) the blowing snow profile would extend to $\sim 10 \mathrm{~m}$ above the ground. The effectively $100 \%$ relative humidity within the blowing snow cloud would render sublimation in this region impossible so that no naked aerosol would be found. Above the blowing snow layer, where entrained subsaturated air would maintain ice evaporation, some naked aerosols are likely to be present. This evaporation process is likely to be slow because the ventilation velocity of the particles is inefficient, being related to the $1 / 8$ th power of the radius (Déry and Taylor, 1996), implying an asymptotic ventilation (and hence evaporation rate) of zero as the ice particle evaporates. However, for a sustained system with sufficient energy, sea salt aerosol generation will certainly occur. Yang et al. (2008) suggest that coarse sea salt particles would have a short lifetime in air, and would thus not be an important source of bromine. Given the amount of turbulence during this blowing snow event, we suggest that the majority of aerosol would be mixed at some point through the blowing snow layer. When this occurs, we suggest that the aerosol would either be scrubbed by the blowing snow (contributing additional salinity to the snow particles) or would condense water vapour onto their surfaces. They would certainly not remain "naked" once within the blowing snow layer.

For the storm of 8 and 9 October, the following scenario thus appears: a saline blowing snow layer that extends to roughly $10 \mathrm{~m}$ above the ground; above the blowing snow layer, an enhanced cloud of aerosol, generated by sublimation of blowing snow. The extreme turbulence of the storm would mix trace gases between these layers and the potential exists for processing (generation, reaction, uptake) within either layer (that is to say, we cannot preclude either substrate as processor based on the observations available). Although we have no profile measurements of either $\mathrm{BrO}$ or $\mathrm{O}_{3}$, if the vertical mixing timescale exceeded the reaction timescale then a vertical gradient in either would be unlikely. Certainly, the fact that $\mathrm{BrO}$ was visible from space suggests that at least some $\mathrm{BrO}$ existed above the blowing snow layer (unless a signal from within the snow layer was accessible as a result of light path enhancement through multiple scattering). It then appears likely that $\mathrm{O}_{3}$ would be severely depleted throughout this turbulently-mixed layer (at least $100 \mathrm{~m}$ ). Given the very large spatial extent of the storm, encompassing effectively the whole of the Weddell Sea region, a significant reduction in regional tropospheric ozone, as well as a significant export of reactive bromine compounds, could be expected as a result.

\section{Summary and conclusions}

On 9 October 2007, satellite observations show that vertical column densities of $\mathrm{BrO}$ were enhanced across the Weddell Sea region of Antarctica. The enhanced $\mathrm{BrO}$ extended over Halley station, providing an opportunity to probe an active event of propagating $\mathrm{BrO}$ and depleting surface ozone using ground-based data. The observations at Halley show that during this event, wind speeds were high and blowing snow was prevalent. Charts of meteorological parameters generated from the ECMWF operational numerical weather prediction system are consistent with such conditions occurring across the Weddell Sea sea ice zone. The observational results demonstrate clearly that the mechanisms driving ODEs are not restricted to those of a shallow stable boundary layer.

We considered the environmental parameters that influence ODEs by modelling how the contact between gaseous and condensed phases (blowing snow in this case) varies with wind speed. The results yielded two maxima, firstly under low wind speeds and a stable boundary layer, and secondly, under high wind conditions. The latter are associated with vigorous turbulent mixing, blowing snow, and ventilation. We conclude that the system is highly dynamic, with aerosol generation and consumption, and, as a result of the turbulent mixing, no vertical gradient in trace gas concentrations. These conclusions should now be tested within an explicit photochemical model complete with suspended surface area data and appropriate radiative parameterisation. Such work would enable scaling up to consider high wind speed mechanisms in modelling calculations that assess the wider influence of ODEs, either the regional radiative response or the associated halogen source. Further, we consider that an assessment of light propagation into blowing snow would advance our confidence in deriving quantitative 
conclusions from satellite observations of $\mathrm{BrO}$ concentrations under blowing snow conditions.

Acknowledgements. The authors gratefully acknowledge the NOAA Air Resources Laboratory (ARL) for the provision of the HYSPLIT transport and dispersion model, available on the READY website (http://www.arl.noaa.gov/ready.html), that was used in this publication. We are grateful to the British Antarctic Survey overwintering staff who carried out the snow pit sampling of 19 October, and to Louise Thilthorpe for carrying out the snow sample ionic analyses. We thank Steve Colwell for making available Halley meteorological data. Analysis of the satellite BrO data was supported by the DFG through the SALT project. Finally we thank Xin Yang for useful discussions, and two anonymous referees for very useful comments.

Edited by: J. W. Bottenheim

\section{References}

Anderson, P. S. and Neff, W. D.: Boundary layer physics over snow and ice, Atmos. Chem. Phys., 7, 7625-7677, 2007,

http://www.atmos-chem-phys.net/7/7625/2007/.

Bovensmann, H., Burrows, J. P., Buchwitz, M., Frerick, J., Noël, S., and Rozanov, V. V.: SCIAMACHY - Mission objectives and measurement modes, J. Atmos. Sci., 56(1), 127-150, 1999.

Burrows, J. P., Weber, M., Buchwitz, M., Rozanov, V., LadstätterWeißenmayer, A., Richter, A., DeBeek, R., Hoogen, R., Bramstedt, K., Eichmann, K. -U., Eisinger, M., and Perner, D.: The Global Ozone Monitoring Experiment (GOME): Mission concept and first scientific results, J. Atmos. Sci., 56, 151-175, 1999.

Culf, A. D.: Acoustic Sounding of the Atmospheric Boundary Layer at Halley, Antarctica, Ant. Sci., 1, 363-372, 1989.

Déry, S. J. and Taylor P. A.: Some aspects of the interaction of blowing snow with the atmospheric boundary layer, Hydrol. Proc., 10(7), 1345-1358, 1996.

Draxler, R. R. and Rolph, G. D.: HYSPLIT (HYbrid Single-Particle Lagrangian Integrated Trajectory) Model access via NOAA ARL READY Website: http://www.arl.noaa.gov/ready/hysplit4.html, NOAA Air Resources Laboratory, Silver Spring, MD, USA, 2003

Fan, S.-M. and Jacob, D. J.: Surface ozone depletion in Arctic spring sustained by bromine reactions on aerosols, Nature, 359, 522-524, 1992.

Foster, K. L., Plastridge, R. A., Bottenheim, J. W., Shepson, P. B., Finlayson-Pitts, B. J., and Spicer, C. W.: The role of Br2 and $\mathrm{BrCl}$ in surface ozone destruction at polar sunrise, Science, 291, 471-474, 2001.

Frieß, U., Hollwedel, J., Konig-Langlo, G., Wagner, T., and Platt U.: Dynamics and chemistry of tropospheric bromine explosion events in the Antarctic coastal region, J. Geophys. Res., 109, D06305, doi:10.1029/2003JD004133, 2004.

Helmig, D., Oltmans, S., Carlson, D., Lamarque, J.-F., Jones, A. E., Labuschagne, C., Anlauf, K., and Hayden, K.: A review of surface ozone in the polar regions", Atmos. Env., 41, 5138-5161, doi:10.1016/j.atmosenv.2006.09.053, 2007.

Hopper, J. F., Yokouchi, Y., Niki, H., Jobson, B. T., Shepson, P. B., and Muthurama, K.: Chemical and meteorological observations during ice camp SWAN during Polar Sunrise Experiment 1992 , J. Geophys. Res., 99(D12), 25489-25498, 1994.

Hopper, J. F., Barrie, L. A., Silis, A., Hart, W., Gallant, A. J., and Dryfhout, H.: Ozone and meteorology during the 1994 Polar Sunrise Experiment, J. Geophys. Res., 103, 1481-1492, 1998.

Jacobi, H.-W., Kaleschke, L., Richter, A., Rozanov, A., and Burrows, J. P.: Observation of a fast ozone loss over frost flowers in the marginal ice zone of the Arctic Ocean, J. Geophys. Res., 111, D15309, doi:10.1029/2005JD006715, 2006.

Jones, A. E., Anderson, P. S., Wolff, E. W., Turner, J., Rankin, A. M., and Colwell, S. R.: A role for newly-forming sea ice in springtime polar tropospheric ozone loss? Observational evidence from Halley station, Antarctica, J. Geophys. Res., 111, D08306, doi:10.1029/2005JD006566, 2006.

Jones, A. E., Wolff, E. W., Salmon, R. A., Bauguitte, S. J. -B., Roscoe, H., K., Anderson, P. S., Ames, D., Clemitshaw, K. C., Fleming, Z. L., Bloss, W. J., Heard, D. E., Lee, J. D., Read, K. A., Hamer, P., Shallcross, D. E., Jackson, A., Walker, S., Lewis, A. C., Mills, G. P., Plane, J. M. C., Saiz-Lopez, A., Sturges, W. T., and Worton, D. R.: Chemistry of the Antarctic boundary layer and the interface with snow: An overview of the CHABLIS campaign, Atmos. Chem. Phys., 8, 3789-3803, 2008.

Kaleschke, L., Richter, A., Burrows, J. P., Afe, O., Heygster, G., Notholt, J., Rankin, A. M., Roscoe, H. K., Hollwedel, J., Wagner, T., and Jacobi, H.-W.: Frost flowers on sea ice as a source of sea salt and their influence on tropospheric halogen chemistry, Geophys. Res. Lett., 31, L16114, doi:10.1029/2004GL020655, 2004.

King, J. C.: Validation of ECMWF sea level pressure analyses over the Bellingshausen Sea, Antarctica, Wea. and Forecasting, 18, 536-540, 2003.

King, J. C. and Anderson, P. S.: Heat and Water-Vapor Fluxes and Scalar Roughness Lengths over an Antarctic Ice Shelf, Bound.Lay. Meteorol., 69(1-2), 101-121, 1994.

König-Langlo, G., King, J. C., and Pettré, P.: Climatology of the three coastal Antarcic stations Dumont d'Urville, Neumayer, and Halley, J. Geophys Res., 103, 10947-10959, 1998.

Lee-Taylor, J. and Madronich, S.: Calculation of actinic fluxes with a coupled atmosphere-snow radiative transfer model, J. Geophys. Res., 107(D24), 4796, doi:10.1029/2002JD002084, 2002.

Lehrer, E., Hönninger, G., and Platt, U.: A one dimensional model study of the mechanism of halogen liberation and vertical transport in the polar troposphere, Atmos. Chem. Phys., 4, 2427 2440, 2004, http://www.atmos-chem-phys.net/4/2427/2004/.

Mann, G. W., Anderson, P. S., and Mobbs, S. D.: Profile measurements of blowing snow at Halley, Antarctica, J. Geophys. Res., 105(D19), 24491-24508, 2000.

McConnell, J. C., Henderson, G. S., Barrie, L., Bottenheim, J., Niki, H., Langford, C. H., and Templeton, E. M. J.: Photochemical bromine production implicated in Arctic boundary-layer ozone depletion, Nature, 355, 150-152, 1992.

Neff, W. D. and Coulter, R. L.: Acoustic Remote Sensing, in: Probing the Atmospheric Boundary Layer, edited by: Lenshow, D. H., Am. Meteorol. Soc., Boston, USA, 201-236, 1985.

Neff, W., Helmig, D., Graches, A., and Davis, D.: A study of boundary layer behaviour associated with high NO concentrations at the South Pole using a minisodar, tethered balloon, and sonic anemometer, Atmos. Env., 42, 2762-2779, 2008.

Rankin, A. M., Wolff, E. W., and Martin, S.: Frost flowers - impli- 
cations for tropospheric chemistry and ice core interpretation, J. Geophys. Res., 107(D23), 4683, doi:4610.1029/2002JD002492, 2002.

Renfrew, I. A., King, J. C., and Markus, T.: Coastal polynyas in the southern Weddell Sea: Variability of the surface energy budget, J. Geophys. Res., 107(C6), 3063, doi:10.1029/2000JC000720, 2002.

Richter, A., Wittrock, F., Eisinger, M., and Burrows, J. P.: GOME observations of tropospheric BrO in Northern Hemispheric spring and summer 1997, Geophys. Res. Lett., 25, 26832686, 1998.

Richter, A., Wittrock, F., Ladstätter-Weißenmayer, A., and Burrows, J. P.: GOME measurements of stratospheric and tropospheric BrO, Adv. Space Res., 29(8), 1667-1672, 2002.

Ridley, B. A., Atlas, E. L., Montzka, D. D., and 29 co-authors: Ozone depletion events observed in the high latitude surface layer during the TOPSE aircraft program, J. Geophys. Res., 108(D4), 8356, 2003.

Rolph, G. D.: Real-time Environmental Applications and Display sYstem (READY) Website: http://www.arl.noaa.gov/ready/ hysplit4.html, NOAA Air Resources Laboratory, Silver Spring, MD, USA, 2003.

Simpson, W. R., von Glasow, R., Riedel, K., et al.: Halogens and their role in polar boundary layer ozone depletion, Atmos. Chem. Phys., 7, 4375-4418, 2007.

Simpson, W. R., Carlson, D., Hönninger, G., Douglas, T. A., Sturm, M., Perovich, D., and Platt, U.: First-year sea-ice contact predicts bromine monoxide $(\mathrm{BrO})$ levels at Barrow, Alaska better than potential frost flower contact, Atmos. Chem. Phys., 7, 621-627, 2007, http://www.atmos-chem-phys.net/7/621/2007/.

Spreen, G., Kaleschke, L., and Heygster, G.: Sea ice remote sensing using AMSR-E $89 \mathrm{GHz}$ channels, J. Geophys. Res., 113, C02S03, doi:10.1029/2005JC003384, 2008.
Tang, T. and McConnell, J. C.: Autocatalytic release of bromine from Arctic snow pack during polar sunrise, Geophys. Res. Lett., 23, 2633-2636, 1996.

Uppala, S. M., Kaallberg, P. W., Simmonds, A. J., and 42 coauthors: The ERA-40 re-analysis. QJRMS, 131(612), 29613012, 2005.

Vogt, R., Crutzen, P. J., and Sander, R.: A mechanism for halogen release from sea-salt aerosol in the remote marine boundary layer, Nature, 383, 327-330, 1996.

Wadhams, P.: Ice in the Ocean, Gordon and Breach Science Publishers, London, UK, 351 pp., 2002.

Wessel, S., Aoki, S., Winkler, P., Weller, R., Herber, A., Gernandt, H., and Schrems, O.: Tropospheric ozone depletion in polar regions: A comparison of observations in the Arctic and Antarctic, Tellus B, 50, 34-50, 1998.

Wagner, T. and Platt, U.: Satellite mapping of enhanced BrO concentrations in the troposphere, Nature, 395, 486-490, 1998.

Wagner, T., Leue, C., Wenig, M., Pfeilsticker, K., and Platt, U.: Spatial and temporal distribution of enhanced boundary layer $\mathrm{BrO}$ concentrations measured by the GOME instrument aboard ERS2, J. Geophys. Res., 106, 24225-24235, 2001.

Wolff, E., Jones, A. E., Bauguitte, S., and Salmon, R.: The interpretation of spikes and trends in concentration of nitrate in polar ice cores, based on evidence from snow and atmospheric measurements, Atmos. Chem. Phys., 8, 5627-5634, 2008, http://www.atmos-chem-phys.net/8/5627/2008/.

Yang, X., Pyle, J. A., and Cox, R. A.: Sea salt aerosol production and bromine release: Role of snow on sea ice, Geophys. Res. Lett., 35, L16815, doi:10.1029/2008GL034536, 2008.

Zilitinkevich, S. and Mironov, D. V.: A multi-limit formulation for the equilibrium depth of a stably stratified boundary layer, Bound.-Lay. Meterol., 81(3-4), 325-351, 1996. 